\author{
Dr. Nagy György \\ Eszterházy Károly Egyetem Sárospataki Comenius Campus \\ Reál Tudományok Intézete \\ nagy.gyorgy@uni-eszterhazy.hu
}

\title{
A TECHNOLÓGIAI KÖRNYEZET ÉS AZ ALSÓ TAGOZATOS KÖRNYEZETISMERET OKTATÁSA
}

\begin{abstract}
Bevezetés
„Merjünk nagyok lenni, s valóban nem olyan nehéz, de legyünk egyszersmint bölcsek is”. Ez a Széchényi idézet soha sem veszíti el az aktualitását. A XXI. század technológiai változásai az oktatásban, annak módszertanában is jelentős átrendeződést indukáltak. Aki nem vesz tudomást erről, az végérvényesen lemarad a kimüvelt emberfők képzési versenyében. Azonban a keretek, és a hozzájuk tartozó minőségi és mennyiségi paraméterek meghatározása nélkül nem volna bölcs dolog ráerőltetni a technológiai környezetet a nevelés és az oktatás bármely szintjére és formájára. Leszükítve az általános iskola alsó tagozatára, a környezetismeret tantárgy kereteire került vizsgálatra a technológiai környezet változásának alkalmazhatósági határa, szükebben az infokommunikációs technológiák (továbbiakban IKT) alkalmazhatósága. A tantárgy nem tartozik az ,és ha nem, hát akkor is” tantárgyak közé, mint a matematika, vagy anyanyelv, ahol írni, olvasni és számolni meg kell tanítani a gyerekeket. A környezetismeret tantárgyi tartalma, ha nem kerül teljes mértékben elsajátításra, akkor sem jelent akadályt a tanuló továbbhaladásában. Ennek van jó és rossz oldala is. Pozitív hatású az, hogy nem stresszeli sem a pedagógust, sem a gyereket a megtanulás-megtanítás kényszere, az órák jó hangulatúak, játékosak, a gyerekek nagy része élvezi azokat, negatív vonzata viszont az, hogy sokszor nem kerülnek a kellő időben a kellö helyre azok az alapok, amelyekre olyan tantárgyakat kell majd felépíteni, mint a fizika, kémia, vagy földrajz, biológia. A tananyag nagyon bőséges, az időkeret szük. A megfelelő módszertan alkalmazása garantálhatja a hatékony munkát. Ebbe a módszertanba kell beépíteni a technológia adta új lehetőségeket. Például az új ismeretet feldolgozó tanóra, akár a hagyományos, akár a konstruktivista tanulásszervezés RJR struktúráját alkalmazva, momentumaiban erre lehetőséget biztosít, azonban a hatékonyságát tekintve jelentős eltéréseket mutat. Előadásomban sorra veszem ezeket a momentumokat, pro és kontra érveket, tapasztalatokat felhasználva, a teljesség igénye nélkül, a technológiai környezet lehetőségeit sorra véve, az alkalmazhatóság határait kísérlem meg meghatározni. Természetesen, mivel nincs két egyforma gyerek, és nincs két egyforma iskola az alkalmazhatóság határainak meghatározásakor a körülményeket is messzemenőkig figyelembe kell venni. A további óratípusok esetében, ha nem is ilyen részletességgel, de hasonló módon vizsgálom a megváltozott technológiai környezet alkalmazhatóságát. Végül kitérek arra, hogy még azokat a kölcsönhatásokat is lehet szemléltetéssel bemutatni, amelyeket veszélyességük, vagy költségvonzatuk miatt a pedagógusok audiovizuális eszközzel, vagy semmilyen módon nem mutatnak be.
\end{abstract}

\section{Problémafelvetés}

A legutóbbi Pisa felmérés [1] alapján elmondható, hogy egyre nagyobb a magyar gyerekek lemaradása a természettudományokban a vezető országokhoz képest, sőt sajnos már az átlagot sem éri el a teljesítményük. A társadalom részéröl az igény megvan, hogy a gyerekeket kellö tudással és hozzáértéssel ruházza fel az iskola, de ennek a gyerekek életkori sajátosságai, illetve 
az ismeretek átadására használható idő szab határt. A használt módszerek nem megfelelőek, a történelem során többször is paradigmaváltásra volt szükség a természettudományok oktatásának területén, módszertani megújítás vezetett az alkalmazható természettudományos ismeretek hatékony elsajátításához. Ilyen váltás volt a szemléltetés módszerének bevezetése Comeniustól, vagy a tanulók cselekedtetésére épülő reformpedagógia. Jelenleg egy újabb lépcsőfokhoz értünk, az infokommunikációs technológia (IKT) hogyan tudja javítani a hatékonyságot az ismeretek átadásának, elsajátításának terén, új dimenziókat felvázolva az ismeretek forrásának tekintetében is. Leküzdhető-e segítségével a növekvő tananyag csökkenő óraszám ellentmondás, a tananyag konstruktivista feldolgozásához nyújt-e segítséget, csökkentheti-e a hiányzó laboratóriumi eszközök által okozott ürt a kísérletek terén, motiváltabb lesz-e általa a tanuló?

\section{Hipotézisek}

1) Az IKT hatékonyabbá teheti a környezetismeret oktatását.

2) A tanóratípusok nem mindegyikében egyforma a szerepe.

3) A tanóra momentumaiban eltérő hatékonysággal alkalmazható.

4) A pedagógus „ellustul”, azokat a lehetőségeket nem biztosítja, amelyekkel a tanulók gyakorlati természettudományos megismerési kompetenciáit fejlesztheti, növelheti.

\section{Történeti elözmények}

A történelem során a társadalmi változások folyamatosan befolyásolták az oktatással kapcsolatos elképzeléseket, ezek megvalósulását. Komolyabb elméleti felkészültség nélkül is elmondható, hogy a tanulás - tanítás területén a folyamat mindig kiforrta magát, a társadalom elvárásai és a gyerekek adottságai megtalálták az ideális konstellációt, azonban az oktatásnak erre adott válasza mindig lépéshátrányban volt a megvalósítás terén. A kisebb-nagyobb változások, paradigmaváltások akkor jelentek meg, amikor az iskolarendszer már nem tudta hatékonyan támogatni a változásokat. Elmondhatjuk, hogy most is elérkeztünk egy ilyen mérföldkőhöz. Az elözmények elemzése után elmondható, hogy amíg a természet diktált, gyakorlatorientált volt az oktatás. Az ősközösségi rendszerben a fiatalok a beavatás után teljes jogú tagjai lettek a törzsnek, az idősebbekkel együtt jártak vadászni, ők voltak a tanítók, tőlük sajátították el az ismereteket induktív módon, a tudás forrása a természet, a sikeres tanulás vizsgája pedig maga az élet, a túlélés volt. Ezt követően a társadalom alárendelte a folyamatot saját érdekeinek. Az ókor és a középkor jelentős részében a fennálló gazdasági és társadalomszervezési rend ettől jelentősen eltérő ismeret átadás-átvételi stratégiát helyezett előtérbe. A gyakorlattól eltávolodtak, a lexikális tudást helyezték előtérbe, a tudás forrásai kódexek és könyvek voltak, a közvetítő a tanító. A tanulók nem lehettek kreatívak, nem kaptak önállóságot. Az ismeretek elsajátítása deduktív alapokon nyugodott, megtanulták a törvényeket és szabályokat, amelyeket a gyakorlatban tanultak meg alkalmazni nem kevés szenvedés által. Nagyon sok ismeret birtokába jutottak, amely pallérozta az elmét és kiszélesítette a memóriát, kellő gyakorlati ismerettel párosulva korszakalkotó eredményeket adott a természettudományok területén.

A mai oktatás gyakorlatában ebből a memóriagyakorlatok maradtak meg, amelyek nem hagyják „ellustulni” az agyat, azonban ezek már jelentősen háttérbe szorultak. Ez a korszak Comenius didaktikai elveinek megszületésével ért véget. A ,nagy tanítómester” nem elégedett meg a könyvek és tanítók által elökészített ismeretekkel, ettől tisztább forrást akart nyújtani a tudásra vágyóknak. A képes világ Comeniusi adaptációja, már nem egy „előemésztett” ismeretet adott, hanem az érzetekből származott valóságot. „Semmi sincs meg a képzetekben, ami ne lett volna meg az érzetekben" - írta [2]. Az élö bemutatás sokkal hatékonyabbnak bizonyult, mint a memorizáláson alapuló rögzítés. A megközelítés induktív, az ismeret forrása 
a természet, a közvetítő viszont még mindig a tanító, az ő általa nyújtott ismeretek várnak elsajátításra. A tanuló még mindig passzív szereplöje az eseménynek, befogadója az ismereteknek, igaz nem csak a hallásán keresztül, de már vizuálisan is. (pl. Comenius Amos Janos: Orbis Pictus). Az igazi nagy áttörést a tanítás-tanulás folyamatában a reformpedagógia jelentette. A tanító az eddigi főszerepet átadta a tanulóknak, mellékszereplővé vált, természetesen még mindig teljes kontroll alatt tartva a folyamatot. Az eddigi passzív befogadó - a tanuló - most aktív részese lett az eseményeknek, az ismeretek értelmi feldolgozása a személyes tapasztalaton, cselekvésen alapul [3]. Azonban amíg a pedagógus szervezi meg a tanuló ismeretszerzését, nem véve figyelembe a tanuló igényeit, nem mondhatjuk el, hogy a pedagógus szürője ki van iktatva az ismeretszerzés folyamatából. A természettudományok területén ez hatványozottan jelentkezik, minden adott az önálló, felfedező munkához, azonban a pedagógus mondja meg mit, mivel, mikor mérjen meg a diák, és milyen eredményt kapjon. A tanulók az ismeretek forrásaivá csak akkor vállnak, ha személyes tapasztalatuk révén (amelyeket nem a tanító személyén és annak megszürésével kapnak, hanem tisztán) szereznek ismereteket és konvertálják a saját rendszerükbe beépíthető modulok formájában. Ekkor lesznek aktív részesei az ismeretek megalkotásának és rendszerbe foglalásának megkonstruálásának.

Így jutunk el a konstruktivizmushoz, mint modern pedagógiai irányzathoz. Természetesen ez a konstruálás nem müködik tiszta lappal, „elözetes ismeretek nélkül nincs tényanyag faldolgozás, elözetes alap nélkül nincs hová beilleszteni a tudás új moduljait." A módszer egyszerre deduktív és induktív [4], az ismeret közvetítője a tanuló de a folyamat irányítója a pedagógus. Az új ismereteket az induktív módon elsajátított megismerö képességek birtokában és a meglévő deduktív alapon nyugvó ismeretek segítségével szerzi meg, dolgozza fel és kapcsolja a meglévő ismereteihez a tanuló. A folyamatban mindkét érintkezési felület változhat, korrigálásra kerülhet - az új ismereté, és a meglévő is, annak megfelelően, hogy tökéletes legyen az illeszkedés, vagyis a megértés, elsajátítás, rögzítés és alkalmazás. A valóságot, vagyis a tudást olyanná alakítja, amely befogadható a tanuló számára. Minél jobb a feldolgozó apparátus és a meglévő tudás, annál közelebb van az elsajátított tudás a valósághoz. Képes-e erre a ránk köszönő technológiai forradalom? Ebben a közvetítő közeg az IKT lenne, az ismeretek forrása pedig a kibertér [5]. A következőkben ennek a környezetismeret terén való alkalmazhatóságát vizsgálom óratípusok és tanórai momentumok szerint.

\section{Elemzés}

Az elemzés elméleti alapjául a környezetismeret tantárgy sajátosságai szolgálnak, amelyek meghatározzák a módszert, és a tartalmat is.

Az óvodás kor érzelmi kapcsolódása a környezethez az alsó tagozaton folyamatosan érzelmivé válik, amely során az általában „,nem szeretem állatok”, mint például a giliszta, béka is hasznos tagjává válik a természetnek a gyerek szemében, megtudva milyen fontos szerepe van az élőlények között. Ilyenkor formálódik a pozitív attitüd a környezet, a természet iránt. A megismerés a gyakorlatban a lehetö legtöbb érzékszervvel történik, ami az adott ismerettel kapcsolatban szóba jöhet. A természettudományos megismerés gyakorlati területei mellett (megfigyelés, kísérlet, mérés) a módszerek között szerepelnek az élmény-, dráma-, múzeum-, zoopedagógia elemei is. Az IKT alkalmazása nagyban hozzájárulhat ezek hatékonyságához, ha kellő időben, és kellő mértékben használjuk.

A tanítás-tanulási folyamat a megfigyelhető, érzékelhető, észlelhető, vizsgálható, esetleg mérhető természeti jelenségekre, élölényekre, folyamatokra épül. [6] A természetismeret tárgy tanításának célja az érdeklődés felkeltése a környezetük élő és élettelen világa iránt, annak megismerése, védelme, mindezt eredményező magatartás kialakítása. [7] Ennek 
eredményeként biztonságosan tájékozódik a térben és időben, környezettudatosan viselkedik a tanuló.

Ennek elsajátítására az új ismeretet feldolgozó óra, a gyakorlati óra, a rendszerező óra és az ellenőrző (értékelö) óra ad lehetőséget. Az órák több mint $80 \%$-át az új anyagot feldolgozó óra teszi ki. Ennek momentumait a klasszikus, Nagy László féle óramodell [8] szerint vettem sorra, amelyikre formailag hasonlít az RJR modell, azonban tartalmilag jelentős eltérést mutat. Az óra jelentős mozzanatai a hagyományos óramodellben: a számonkérés (vagy ismétlés), ismeretszerzés- alkalmazás (tanulásszervezési rész), ellenőrzés és értékelés. Az RJR modell esetében a tanulásszervezési rész a ráhangolódásból, jelentésteremtésből és a reflektálásból áll (a szavak kezdőbetüi adják a modell nevét is).

A számonkérés, esetében az a megszokott, hogy 1-2 tanuló feleltetése szóban történik, 4-5 tanuló pedig ezalatt írásban felel. Az osztály figyelemmel kíséri az eseményeket, közben ismétel is. Az IKT a szóbeli feleletet nem váltja ki, momentumaiban segíthet, azonban a feladatlapos megoldásra sokkal hatékonyabb megoldást kínál, mint a hagyományos forma. Míg a hagyományos esetben a feladatlapot csak óra után ellenőrizhetjük, időhiány miatt, a technológia ezt megteszi helyettünk, és a tanulónak nem kell a következő óráig várnia (izgulnia), hogy megtudja az eredményt, hanem a kellö hardveres (amin a tanuló kitölti a feladatlapot) és szoftveres (ami kijavítja a munkát) háttér segítségével azonnal rendelkezésre áll az eredmény, a hibák és a jó megoldások feltüntetésével. Ennek is lehetnek buktatói, pl. ha a tanuló nem tudja kezelni az eszközt.

A motiváció alkalmával több módszer is alkalmazható különböző hatékonysággal. Az újdonság, az élmény lehet motiváló IKT eszközzel, de az érdeklődést, belső kíváncsiságot (intrinzik) nem tudja egy digitális eszköz olyan szinten gerjeszteni, mint egy élő bemutatás, látványos kísérlet vagy váratlan esemény ( $\mathrm{pl}$. egy rendör megjelenése teljes felszerelésben mivel ezen az órán a rendőrség munkája a tananyag). A célkitüzés megjelenése az interaktív táblán kevésbe gondolkodtató a tanulók számára, mint az, hogy arra a motivációból maguk jöjjenek rá. Természetesen ezután megjelenhet.

Az új anyag feldolgozása innen veszi kezdetét. A tananyagtól függően a meglévő ismeret aktiválása külön részben történhet, vagy az új ismeret megszerzésével párhuzamosan történik. A meglévő ismeret valaha valamilyen gyakorlati tevékenységböl kiindulva, annak segítségével vált ismeretté, majd ezt követően a szokásos módon vésődött be. A pedagógus döntése, hogy ennek a folyamatnak melyik részét eleveníti fel, melyik szolgálja a legjobban az ismeret aktivizálását. Erre a célra kifejezetten alkalmas az IKT technológia, gyorsasága, információtartalma, vizualitása miatt, ahol már elég egy, vagy két érzékszerv az ismeretek felidézéséhez.

Az új ismeret átadása esetében, nagyon kevés az a tananyag, ahol a tanítói leleményesség és kreativitás ne tenné lehetővé a gyakorlati ismeretszerzést a lehető legtöbb érzékszerv segítségével. Vannak kifejezetten olyan tananyagok, amelyeket IKT-val lehetetlen maradéktalanul átadni. Be lehet mutatni a barack képét, fejlődését, esetleg hangját is, amikor leesik a fáról, de a tapintását, illatát, ízét még nem képes visszaadni a legmodernebb IKT sem. Arról nem is szólva, hogy különböző élménypedagógiai elemekkel lehet kombinálni a megismerést (pl. varázsdoboz).

A szerzett ismeretek logikai feldolgozását a tanuló végzi több (hagyományos) vagy kevesebb (konstruktivista) tanítói ráhatással, befolyásolással. Az IKT segíthet a tanítónak abban, hogy a tanuló által megkonstruált ismeret minél jobban közelítsen a valósághoz, rendezéssel, rendszerezéssel. A rögzítés során is alkalmazhatunk IKT eszközöket kombinálva az alkalmazás lehetőségeivel (a logikai rögzítést, vagyis az új ismeret kapcsolását a meglévő ismerethez, sémához a tanuló végzi). A munkatankönyv, vagy munkafüzet feladatait digitális platformon megoldhatja a tanuló, azonban ez hatékonyságában messze alulmarad annál, amit egy kísérleti eszközökkel megoldott probléma adhat (pl. homok, fürészpor és víz szétválasztása). Az 
eszközhasználat, a hozzá tartozó finom-motorika az elterjedt IKT eszközökkel nem fejleszthető, a speciális konzolok fejleszthetik azokat (pl. PS, XBOX), de nem biztos, hogy ez a megtanult mozgássor biztosítja a laboreszközök készségszerü használatát.

Az összefoglalás, ellenőrzés, mivel általában kevés időt szán rá a tanító, vagy kevés idő jut rá egy túltervezett órán IKT eszközökkel gyorsan és hatékonyan végrehajtható, több információ is kinyerhető belőle, pl. a hozzáadott pedagógiai értékről, ha a hagyományos frontális kérdésfelelet, vagy igaz-hamis állítások helyett jelöléstáblát alkalmazunk. Ennek lényege az, hogy az adott órán átadott konkrét ismerettel kapcsolatban a tanuló nyilatkozik arról, hogy ezt eddig is tudta, vagy eddig nem így tudta, eddig nem tudta, és érti is, eddig nem tudta, de most sem érti, illetve olyan érdekes volt, hogy otthon is utána néz, vagy elvégzi a kísérletet. Egy ilyen táblázat kitöltése könnyen megtanítható a tanulóknak, ennek a kezelését és ellenőrzését a megfelelő szoftver azonnal elvégezheti, a kellő információkat szolgáltatva a pedagógusnak.

Az értékelést természetesen semmilyen körülmények között ne adja át a pedagógus az IKTnak, a személyes kapcsolat nagyon fontos a gyerek lélektani fejlődésének szempontjából.

A gyakorlati óra eleje és vége hasonló felépítésű, mint az új anyag feldolgozó óráé. Az óra központi része azonban teljesen eltér ettől. Itt már az alkalmazásé a föszerep. A gyakorlati ismeretek elsajátítása IKT keresztül szinte lehetetlen, hiszen itt olyan tevékenységekről van szó, mint a megfigyelés (nagyítóval, távcsővel, mikroszkóppal), kísérletezés (eszközhasználat, vegyszerhasználat), mérés (tömeg, térfogat, idő, hőmérséklet) vagy a tananyaggal kapcsolatos gyakorlati tevékenység (lágy-, fásszár, oldódás, olvadás, párolgás, forrás, stb.).

A rendszerező (ismétlő - összefoglaló) óra, a gyakorlati órához hasonlóan a központi részében különbözik az új anyag feldolgozó órától. A rendszerező óra tökéletesen alkalmas arra, hogy a tanulók IKT segítségével oldják meg a feladatokat, hajtsák végre a csoportosítást, osztályozást, válogatást, rendezést. Itt már nem azon kell elgondolkodnia a pedagógusnak, hogy használ-e IKT-t, hanem azon, hogy milyen pedagógiai elemekkel teszi azt hatékonyabbá (élmény-, drámapedagógia, stb.)

A hagyományos ellenőrző (értékelö) óra esetében a témazáró feladatlap kitöltésével telik el az óra, amit óra után javít ki a pedagógus, ezt a következő órán visszaadja a tanulóknak áttekintésre, és ha nagyon siet, az új téma terjedelme miatt, nincs idő a helytelen megoldások megbeszélésére (esetleg napköziben visszatérhet rá). Digitális platform esetében, a megfelelő feladattípusok összeválogatásával lerövidíthetjük a megoldásra szánt időt, a javító szoftver elvégzi a javítást, értékelést, a tanuló még órán megtudja az eredményét, és nem kell izgulnia a következő óráig, hogy milyen lett a témazárója. A program statisztikát is készíthet a helyeshelytelen feladatokról, és a hátralévő időben a leggyakrabban előforduló hibák megbeszélésre, javításra kerülhetnek. A pedagógus, mivel nem kell javítania több szabadidővel rendelkezik, ami a növeli a pedagógiai munkájának hatékonyságát.

Összegezve a leírtakat, akkor miért nem tudjuk hatékonyan alkalmazni az IKT-t, és miért nem vált általánossá? Négy tényező megléte kell ahhoz, hogy a tervből valóság legyen. Az egyik tényező a hozzáértő pedagógus, a másik a hardveres háttér, amihez harmadik tényezőként a szoftveres ellátottság szükséges, az utóbbi kettő komoly anyagi ráfordítást igényel. Negyedikként pedig mindez a hozzáértő tanulók nélkül nem ér semmit, használhatatlan. Szerencsére az utóbbi, a kompetencia kifejlesztése, a mai kor gyermekének ( $Z$ és $\alpha$ generáció) már természetes, használatának elsajátítása sokkal könnyebben történik, mint a hozzáértő pedagógusok képzése, vagy kinevelése.

Nem alkothatunk teljes képet az IKT alkalmazhatóságáról a nélkül, hogy megemlítsük a pedagógus felelősségét. A túlterhelt pedagógus hajlamos arra, hogy a kisebb hatékonyságú, de kevesebb felkészülést igénylő módszertant választ, csupán IKT-ra támaszkodik. Ebben az esetben egy idő után a tanító is elveszti kreativitását, de ekkorra a tanulói már régen elfordultak a természettudományoktól. Azoknál a pedagógusoknál pedig, akik még a lehetetlent is be tudják mutatni tantermi körülmények között (pl. a forrást vákuumszivattyú helyett fecskendővel, a 
lebegést szélcsatorna helyett szívószállal, vagy a Magdeburgi féltekéket egy pohár víz és méretre vágott fólia segítségével) a tanulók jó alapokat kapnak a későbbi természettudományos tanulmányaikhoz.

\section{Konklúzió}

1) Az elemzés alapján elmondható, hogy az IKT hatékonyabbá teheti a környezetismeret oktatását, megfelelő, hozzáértő módon alkalmazva.

2) A különböző tanóratípusok esetében eltérő hangsúllyal kerülhetnek alkalmazásra, mert más a hatékonyságuk, különösen az új anyag feldolgozó és gyakorlati órán.

3) A tanóra momentumaiban a pedagógus egyedi elbírálása alapján a tananyagtól függően alkalmazható, az új ismeret szerzése, tényanyaggyüjtés, illetve a gyakorlati alkalmazás esetén csak végső soron alkalmazzuk, ha más, gyakorlatiasabb megoldás nem áll rendelkezésünkre.

4) A kevésbé, vagy egyáltalán nem elkötelezett pedagógus, aki csak szakmának tekinti a tanítást és nem hivatásnak, könnyen a könnyebb utat választja, csak IKT-ra támaszkodik, elveszíti kreativitását, „kiírtja” a tanulóiban meglévő természettudományos érdeklődést is.

\section{Irodalomjegyzék}

[1] Siralmas a magyar diákok eredménye a PISA-teszten (2016). URL: http://eduline.hu/kozoktatas/2016/12/6/Borzaszto_a_magyar_diakok_eredmenye_a_PIS At_URT069

[2] Comenius Ámos János (1896). Nagy oktatástan.(ford. Dezső Lajos). Sárospatak: Steinfeld Jenő

[3] Nahalka István (2002). Hogyan alakul ki a tudás a gyerekben: Konstruktivizmus és pedagógia. Budapest: Nemzeti Tankönyvkiadó

[4] Jean Piaget (1970). Válogatott tanulmányok. Budapest: Gondolat

[5] Komenczi Bertalan (2009). Elektronikus tanulási környezetek. Budapest: Gondolat

[6] Havas Péter (2009). A természetismeret tantárgy helyzetérôl. URL: http://ofi.hu/tudastar/tanitastanulas/termeszetismeret

[7] Nemzeti Alaptanterv (2012). In: Magyar közlöny

[8] Nagy László (1972). Didaktika gyermekfejlödési alapon. In: Nagy László válogatott pedagógiai müvei. Budapest: Tankönyvkiadó 